\title{
The journey to death; asian swamp eel fate in a non- native habitat
}

Keywords: Synbranchidae, habitat, spawning event, eggs, Monopterus

\section{Introduction}

Asian Swamp eels belong to Synbranchidae family. ${ }^{1}$ They live in fresh water and they hide in the mud when the water supply dries up. Most eel species are hermaphroditic because they start their life as females then later change into males, although there is a small number of individuals are born and remain as male throughout their lives. ${ }^{2}$ Spawning can happen throughout the year. Females can produce up to 1,000 eggs during the spawning event, eggs are laid in bubble nests float at the water surface. These bubble nests located in shallow waters. ${ }^{3}$

\section{Native habitat}

Asian swamp eel Originating from tropical and subtropical areas of Asian countries including India, Burma, Indonesia, Malaysia, Japan, and China. ${ }^{4}$

\section{Non-native habitat}

The Asian swamp eel was first introduced into the Hawaiian Islands in $1900,{ }^{5}$ and in 1990, it was introduced to different ponds near Atlanta and Georgia, within the Chattahoochee River drainage basin. ${ }^{6}$ In 1993, there are two more populations of the eel have been discovered; one outside of Tampa, Florida, and one in southern Georgia near the Chattahoochee River. ${ }^{7}$ In 1997, eel was collected in the southeast and in west- central of Florida. ${ }^{8}$ It has been reported that the introduction of Asian swamp eel into Georgia as an aquarium release, and to Florida it might be because aquarium release, escape from fish farm or release of from the life fish market. ${ }^{9}$

\section{Ecological effects}

There is concern in Georgia and Florida, that the species will spread to adjacent water areas as has happened in the Everglades region of Florida. ${ }^{10}$ It has been reported that the presence of internal parasites in the imported and wild-caught swamp eels from a U.S. retail food market as well as from the population which introduced in Florida, finding parasites in almost all the specimens means that Monopterus can be a vector for introduction of macroparasites. ${ }^{11}$ However, due to their weak swimming, small mouths, poor vision, slow growth and other eco-morphological characteristics, it seems unlikely that swamp eel will cause major ecological or economic problems in Florida. Nonetheless, the effects of largely and randomly introduced of Asian swamp eel are difficult to predict, a practical effort should be made to prevent future introductions of this species. ${ }^{8}$

\section{Control}

The United States Geological Survey (USGS) recommended different methods to control the Monopterus albus population in Southern Florida. Selected water management practice has been established to control swamp eel populations by not open the water supply especially into the waters of Everglades National Park.9
Volume 7 Issue 5 - 2018

\author{
Ayah Rebhi Hilles,' Syed Mahmood, ,,3 Mohd \\ Arifin Kaderi,' Ridzwan Hashim' \\ 'Department of Biomedical Sciences, International Islamic \\ University Malaysia, Malaysia \\ ${ }^{2}$ Department of Pharmaceutical Engineering, University Malaysia \\ Pahang, Malaysia \\ ${ }^{3}$ Centre of Excellence for Advanced Research in Fluid Flow \\ (CARIFF), University Malaysia Pahang, Malaysia
}

Correspondence: Ayah Rebhi Hilles, Department of Biomedical Sciences, International Islamic University Malaysia, Malaysia,Email ayah.halles90@gmail.com

Received: September 19,2018 | Published: October 12, 2018

Electrofishing capture has been used to control Asian swamp eel and its efficiency was $48 \%{ }^{8}$ It has been recorded that serial pesticide dilutions of antimycin-A were tested against Asian swamp eel and it found to be ineffective as there was no change in morbidity or mortality. ${ }^{12}$ It has been conducted that 2 and $4 \mathrm{mg} / \mathrm{L}$ concentrations of rotenone were able to kill most of the small eels, while $100 \%$ mortality against adult swamp eels was achieved only at $8 \mathrm{mg} / \mathrm{L}$ of rotenone, this method was established in Florida to control swamp eels. ${ }^{13}$ Even though there are many factors effect on Asian swamp eels but controlling them in the non-native habitat consider as a big challenge, ${ }^{14}$ and this might be due the wide range of Asian swamp eel species as it has 24 species. $^{15}$

\section{Conclusion}

The Asian swamp eel has an incredible ability to survive in adverse conditions, it can adapt in cold and hot environment, it can survive in the dry season while other non-native species normally die. This species multiply quickly because all the offspring are female when they born so there is a large number of eggs can be produced each spawning. Ecological threat of Asian swamp eel has shown to displace the native species also accelerate the drying out of shallow waters because of the huge burrow systems they reside in, therefore the American fisheries society is investigating methods for control and eradication of Asian swamp eel.

\section{Acknowledgements}

None.

\section{Conflict of interest}

The authors declared that there is no conflict of Interest.

\section{References}

1. Perdices A, Doadrio I, Bermingham E. Evolutionary history of the synbranchid eels (Teleostei: Synbranchidae) in Central America and the Caribbean islands inferred from their molecular phylogeny. Molecular Phylogenetics and Evolution. 2005;37(2):460-473. 
2. Johnson GD, Gill AC, Paxton JR, et al. Encyclopedia of Fishes. Bangladesh; 1998.

3. Chivers CJ. Swamp aka rice eels. Wildlife Conserv. 1999;102-108.

4. Collins TM, Trexler JC, Nico LG, et al. Genetic diversity in a morphologically conservative invasive taxon: multiple introductions of swamp eels to the southeastern United States. Conservation Biology. 2002;16(4):1024-1035.

5. Devick WS. Patterns of introduction of aquatic organisms to Hawaiian freshwater habitats: in Devick, WS, New Direction in Research. Management and Conservation of Hawaiian Freshwater Stream Ecosystems; 1991.

6. Reinert TR, Straight CA, Freeman BJ. Effectiveness of Atimycin-A as a Toxicant for Control of Invasive Asian Swamp Eels. North American journal of fisheries management. 2006;26(4):949-952.

7. Daerr EG. Asian Swamp Eel Invades Florida. National Parks. 2000;74(6):13-14.

8. Shafland PL, Gestring KB, Stanford MS. An assessment of the Asian swamp eel (Monopterus albus) in Florida. Reviews in Fisheries Science. 2009;18(1):25-39.
9. Turkewitz J. Alien eels slither close to Hooch: Researchers fear creatures could disrupt ecosystem. The Atlanta-Journal Constitution. 2006;7(25):1-4.

10. Kline JL, Loftus WF, Kotun K, et al. Recent fish introductions into Everglades National Park: an unforeseen consequence of water management? Wetlands. 2014;34(1):175-187.

11. Nico LG, Sharp P, Collins TM. Imported Asian swampeels (Synbranchidae: Monopterus) in North American live food markets: Potential vectors of non-native parasites. Asia; 2011.

12. Pherson BF. Water Quality in Southern Florida. USA; 1998.

13. Schofield PJ, Nico LG. Toxicity of 5\% rotenone to nonindigenous Asian swamp eels. North American Journal of Fisheries Management. 2007;27(2):453-459.

14. Ayah RH, Syed M, Ridzwan H. Review about the Factors Effect on Asian Swamp Eel (Monopterus Albus). Current trends in biomedical engineering \& biosciences. 2018;15(3).

15. Ayah RH. Classification of Asian Swamp Eel Species. Current trends in biomedical engineering \& biosciences. 2018;15(1). 